\title{
Femtogram per Milliliter per Milligram per Kilogram
}

National Cancer Institute

\section{Source}

National Cancer Institute. Femtogram per Milliliter per Milligram per Kilogram. NCI

Thesaurus. Code C119338.

A unit of concentration equal to femtogram per milliliter, divided by milligrams per kilogram. 